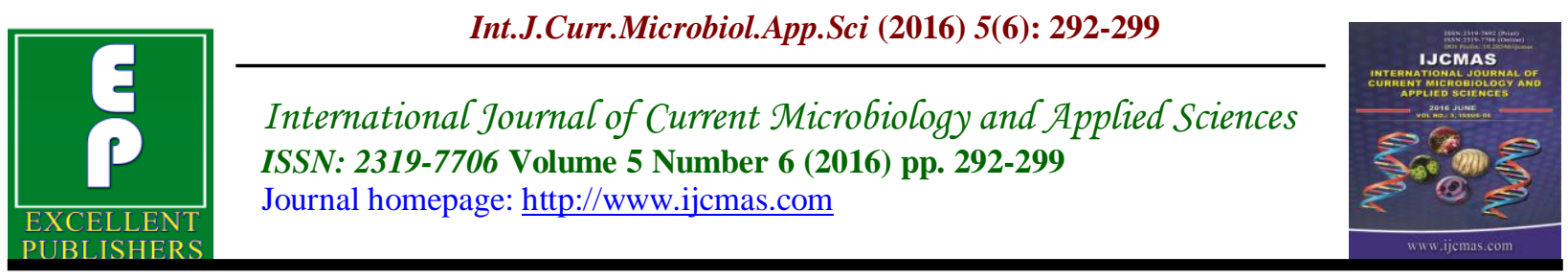

Original Research Article

http://dx.doi.org/10.20546/ijcmas.2016.506.033

\title{
Process Optimization for Bioscouring of Cotton Fabrics with Pectinase obtained from Paecilomyces variotii
}

\author{
M.K. Nisha* \\ Avinashilingam Institute for Home Science and Higher Education for \\ Women (University), Coimbatore -43, Tamilnadu, India \\ *Corresponding author
}

\begin{abstract}
A B S T R A C T
Keywords

Bioscouring,

Desizing,

Paecilomyces

variotii,

Cotton fabrics.

Article Info

Accepted:

15 May 2016

Available Online:

10 June 2016

The present investigation revealed that the bioscouring process performed with the obtained optimal values was suitable for pre-treatment of cotton fabrics by pectinase secreted from the pectinolytic fungus, Paecilomyces variotii. The purified pectinase obtained from $P$. variotiiwas lyophilized and it was compared with the crude and commercial pectinase for bio scouring of cotton fibers in the textile industry. In textile application, prior to the bioscouring, cotton fabric was subjected to the pre-treatment with desizing to remove the impurities. Crude, purified and commercial pectinase were optimized for the bioscouring process and the results of the study revealed that the optimized conditions of pectinase for bioscouring on pre-treated cotton fabrics selected were $40 \%$ enzyme concentration, $4 \mathrm{~h}$ treatment time, $40^{\circ} \mathrm{C}$ temperature and $\mathrm{pH} 5.0$ respectively. Based on the results of the study it can be understood that the bioscouring process performed with these optimal values is suitable for pre-treatment of cotton fabrics.
\end{abstract}

\section{Introduction}

Enzymes are bio-active compounds or catalyst that regulates many chemical reactions in living tissues and cells (Prathyusha and Suneetha, 2011). These enzymes have useful applications in paper, fruit and textile industries. Almost $75 \%$ of the estimated sale value among industrial enzymes in 1995 has been contributed by pectinases. As a result, Pectinase became one of the futuristic useful enzymes in commercial sector (Kashyap et al., 2001). Pectinase is an enzyme of high molecular weight, negatively charged, acidic glycosidic macromolecules that breakdown complex polysaccharides in plant tissues into simpler molecules with extraordinary specificity, catalytic power and substrate specificity (Approvi and Vuppu, 2012). Primarily, these enzymes are responsible for the degradation of the long and complex molecules called pectin that occur as structural polysaccharides in the middle lamella and the primary call walls of young plant cells.

Pectinases from food and food bio products processed waste, alone account to a total of one-third quarter of world's food enzyme production and are one of the upcoming enzymes of the commercial sector today. 
Byproducts or waste obtained from orange, apple, grapes, pine apple, papaya, lemon juice manufacturing industries are used as source for the enzyme production (Prathyusha et al., 2011). Identification and bioconversion of locally available agrowaste is advantageous as it not only leads to the value addition of these residues, but also helps to keep the environment clean. Agro industrial by products can be successfully utilized for the microbial pectinolytic enzyme production and as these residues are locally abundant low cost raw materials, they can be used for cost effective enzyme production. Microbes are rich source of enzymes and the exploration of extracellular enzymatic activity from them has formed the basis of industrial enzymes of which, 50 per cent is from fungi and yeast, 35 per cent from bacteria and the remaining 15 per cent are from either plant or animal origin. Fungi, with their well characterized biology, have been widely exploited as sources of industrially important enzymes. Fungal pectinases are mainly extracellular enzymes, prominent among them being polygalacturonase, which is also the most commonly assayed to determine pectinase activity.

Pectinases have wide applications which include clarification of wine and juice, scouring of cotton, degumming of plant fibres, waste water treatment, vegetable oil extraction, tea and coffee fermentations, bleaching of paper, and in poultry feed additives (Rangarajan et al., 2010). In textile industry, bio-scouring is a novel process for removal of non-cellulosic impurities from the fibre with specific enzymes. Pectinases have been used for this purpose without any negative side effect on cellulose degradation (Hoondal et al., 2000).The chemical degumming treatment is toxic and nonbiodegradable but using pectinases in combination with xylanases presents an eco- friendly and economic alternative to the problem (Kapoor et al., 2001). Pectins are responsible for the hydrophobic properties of raw cotton and its degradation by pectinolytic enzymes was also suggested to facilitate the removal of waxes and could thus lead to a considerable reduction rate of water and chemicals consumption.

\section{Materials and Methods}

\section{Selection of Fabrics}

Greige and plain weaved 100 percent cotton of $130 \mathrm{~g} / \mathrm{m}^{2}$ weight was selected for the study.

\section{Pre-treatment of Cotton Fabric}

\section{Desizing}

The first step of wet pre-treatment is the removal of starch or other sizing materials to increase the absorption which are applied on yarn before weaving, for better weavability. The process is known as desizing. The fabrics were desized by boiling in a solution containing one per cent hydrochloric acid for 3 hours using a Material Liquor Ratio (MLR) of 1:30 and thoroughly washed with cold water and dried in air (Samantha et al., 2003 and Dalvi et al., 2007).

\section{Scouring of Cotton Fabrics}

\section{Conventional Scouring Process}

The sample cotton material was weighed accurately and then steeped in the solution containing caustic soda, soda ash and wetting agent at $40 \mathrm{oC}$. The temperature of the solution was increased uniformly to boil the cotton material for two hours. The cotton material after scouring was washed first with hot water and then, with cold water thoroughly to remove the impurities and 
chemicals. It was then, dried in an oven and weighed accurately to calculate the weight loss from the cotton after scouring

\section{Bio Scouring}

The pectinase enzyme obtained from Paecilomyces variotii (crude and purified) and commercial pectinase were employed in bio scouring process

\section{Optimization of Different Parameters for Bio Scouring}

\section{Concentration of Enzyme}

To determine the optimum concentration of enzyme, (crude, purified and commercial) the bio scouring was carried out by taking the enzyme in different concentrations like $1: 3,1: 1,3: 1$ and $0: 1$.

\section{Treatment Time}

To determine the optimum treatment time, the bio scouring bath containing the selected fabric samples with different enzyme concentrations $(1: 3,1: 1,3: 1$ and $0: 1)$ were individually incubated at different time intervals such as 2, 4, 6, 8 and $10 \mathrm{~h}$. After the specified duration, each sample was washed with hot water and cold water and shade dried. The percentage

weight loss was calculated for all the fabrics.

\section{Temperature}

To determine the optimum temperature, bioscouring was carried out at various temperatures such as 40, 45, 50, 55, 60 and $65^{\circ} \mathrm{C}$ at optimum treatment time and concentration $(1: 3,1: 1,3: 1$ and $0: 1)$.

\section{pH}

The bio scouring bath was adjusted at different $\mathrm{pH}$ ranges of 5.0, 6.0, 7.0 and 8.0 in $1 \mathrm{~N} \mathrm{HCl}$ or $\mathrm{NaOH}$ with different enzyme concentrations $(1: 3,1: 1,3: 1$ and $0: 1)$. The efficiency of bio scouring was evaluated by calculating per cent weight loss of the fabrics. Bio scouring was done by taking material liquor (M: L) ratio as 1:20. In the liquor ratios of 20, different volumes of crude, purified and commercial pectinase namely $1: 3,1: 1,3: 1$ and $0: 1$ was taken in four different beakers. Four samples of cotton each weighing $1 \mathrm{~g}$ were dampened in distilled water and immersed in the different enzyme solution for different incubation period. Finally, samples were given a hot wash followed by cold wash. Then, the fabrics were dried in shade and weighed.

\section{Results and Discussion}

Pre-treatment of the fabric

Desizing and scouring of the cotton materials

From Table 1, it is clear that the weight of samples decreased after the pre-treatment when compared to original. The loss in weight is the result of removal of starch, dirt and other oil substances. The percentage weight loss in desized sample was 17.02 percent and in scoured sample was 4.81 percent over original (untreated).

The present study is on par with the findings of Prang Rocky (2012) who recorded 6.56 percent weight loss after conventional scouring on jersey. Similar view was expressed by Harane et al., (2014) who reported $10.5 \%$ weight loss after desizing process on the grey fabric from total amount of size present on the fabric (12\%). Schimper et al., (2006) reported that after 8 $\mathrm{h}$ hydrolysis, the weight loss in viscose, modal, lyocell and cotton were $50 \%, 13 \%$, $5 \%$ and $22 \%$ respectively. 


\section{Optimization of Different parameters for bio scouring}

\section{Enzyme concentration (Figure 1)}

Among the different concentrations (20,40, 60, 80 and 100) of enzymes (crude, purified and commercial), maximum weight losses of 60,60 and70 percent respectively, were recorded at 40 percent enzyme concentration, after that, it declined irrespective of the type of enzyme used. Hence, the optimum enzyme concentration was found to be 40 percent for bio scouring.

Sikder et al., (2012) observed a weight loss of 2.7 and $2.5 \%$ of fabric when treated with 1.5 and $1 \%$ concentration of Bio - Scouring agent, and of 2.9 and $2.8 \%$ of weight loss was observed when fabric was treated with 2 and $1 \%$ concentration of Scouring agent. Siddiquee (2014) treated 100\% cotton single jersey fabric and observed a weight loss percent of $4.75 \%, 5.77 \%$ and $5.73 \%$ for 2,4 and $6 \mathrm{~g} / \mathrm{l} \mathrm{NaOH}$ and 3.54, 2.96, 3.56, 2.97, and $2.57 \%$ for $0.5,1.5,2.0,2.5,3.0 \mathrm{~g} / \mathrm{l}$ enzyme concentration, respectively .

\section{Treatment Time}

The percentage weight loss in enzyme treated cotton fabrics showed an increasing trend with treatment time up to $4 \mathrm{~h}$ after that, it declined gradually (Figure 2).

Among the different time intervals $(2,4,6,8$ and 10h) maximum weight loss of 40,60 and 80 percent respectively were recorded at $4 \mathrm{~h}$ for the crude, purified and commercial treated fabrics at 40 percent enzyme concentration. Hence, the optimum treatment time was found to be $4 \mathrm{~h}$ for bio scouring.

Rajendran et al., (2011) stated that as the scouring period increased the weight loss increased proportionately and reported that $1.88 \%$ reduction in the weight was observed for the sample scoured for a period of 50 min.

pH

Among the different $\mathrm{pH}$ range $(5.0,6.0,7.0$ and 8.0), at an optimum of 40 percent enzyme concentration for $4 \mathrm{hrs}$.of incubation time, maximum weight losses of 40, 60 and 70 percent were noticed at $\mathrm{pH} 5.0$ in crude, purified and commercial pectinases treated cotton fabrics. An increasing trend in the percentage of weight loss was noticed upto pH 5.0 in enzyme treated cotton fabrics (Figure 3). Hence, the optimum $\mathrm{pH}$ for bio scouring was fixed as 5.0, thus, proving the enzymatic treatments to be acidic for subsequent experiments.

Tzanov et al., (2001) reported that the lower enzyme of $70 \mathrm{U} / \mathrm{g}$ cotton, reduced the weight loss percent by $25-27 \%$ in the enzymatic process. Thus, alkali pectinase has proved a similar performance to the acidic enzyme, even in lower concentrations, which is beneficial from an economic point of view. The present result is on par with Rajendran et al., (2011) who observed a considerable weight loss of the fabric at $\mathrm{pH}$ 5.0. According to the work of Klug (2004), the iso electric point for pectatelyase was at $\mathrm{pH} 8.5$ which coincides with its maximum activity. The pectin removal efficiency of pectinase reduced drastically above $\mathrm{pH}$ 9.0.

\section{Temperature}

It may be inferred from the Figure 4, that the percentage weight loss showed an increase in enzyme treated cotton fabrics at $40 \mathrm{oC}$ and after that it declined gradually. Among the temperature ranges $(40,45,50,55,60$ and $650 \mathrm{C}$ ), a maximum weight losses of 60,70 
and 80 percent were noticed at an optimum temperature of $40^{\circ} \mathrm{C}$, when cotton fabric was treated with crude, purified and commercial pectinases respectively in the optimum conditions of $40 \%$ enzyme concentration, $\mathrm{pH} 5.0$ and incubation time of 4 hrs. Hence, $40^{\circ} \mathrm{C}$ was found to be the optimum temperature for bioscouring of cotton fabric.

Table.1 The effect of pre-treatment of cotton fabric

\begin{tabular}{||c|c|c|c||}
\hline $\begin{array}{c}\text { Fabric } \\
(\mathbf{1 ~ m})\end{array}$ & Initial weight (gm) & Final weight (gm) & $\begin{array}{c}\text { Weight loss in } \\
\text { percent }\end{array}$ \\
\hline Desized & 193 & 160.15 & 17.02 \\
\hline Scoured & 160.15 & 152.44 & 4.81 \\
\hline
\end{tabular}

Table.2 Optimized conditions for bioscouring of cotton using pectinase

\begin{tabular}{||l|c|c|c|c||}
\hline $\begin{array}{c}\text { Enzyme treatedcotton } \\
\text { samples }\end{array}$ & Concentration(\%) & Treatment(hrs.) & Temperature $\left({ }^{\mathbf{0}} \mathbf{C}\right)$ & $\mathbf{p H}$ \\
\hline Crude pectinase & 40 & 4 & 40 & 5.0 \\
\hline Purified pectinase & 40 & 4 & 40 & 5.0 \\
\hline Commercial pectinase & 40 & 4 & 40 & 5.0 \\
\hline
\end{tabular}

Fig.1 Optimization of enzyme concentration for bioscouring by pectinase (wt. loss\%)

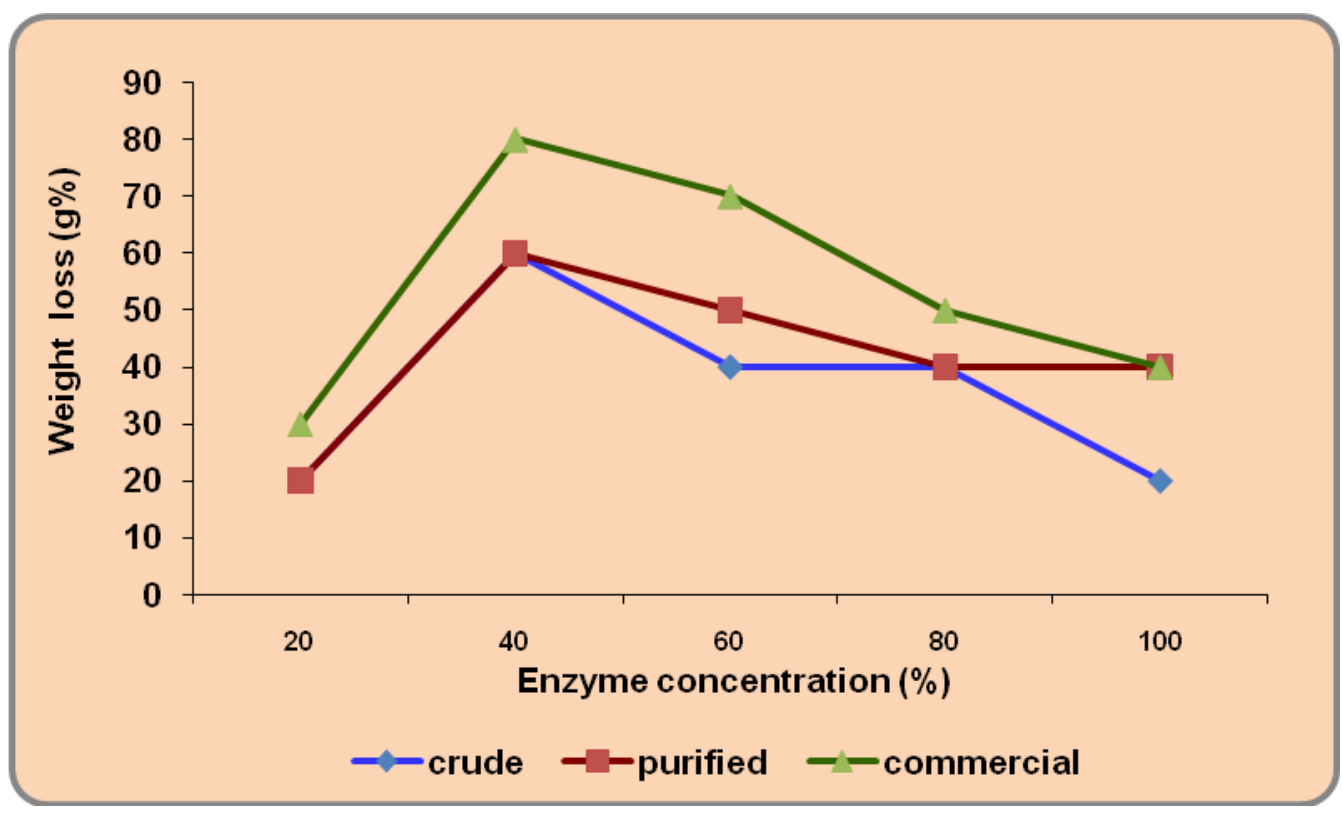


Fig.2 Optimization of incubation time for bioscouring by pectinase (wt. loss \%) at an optimum of $40 \%$ enzyme concentration

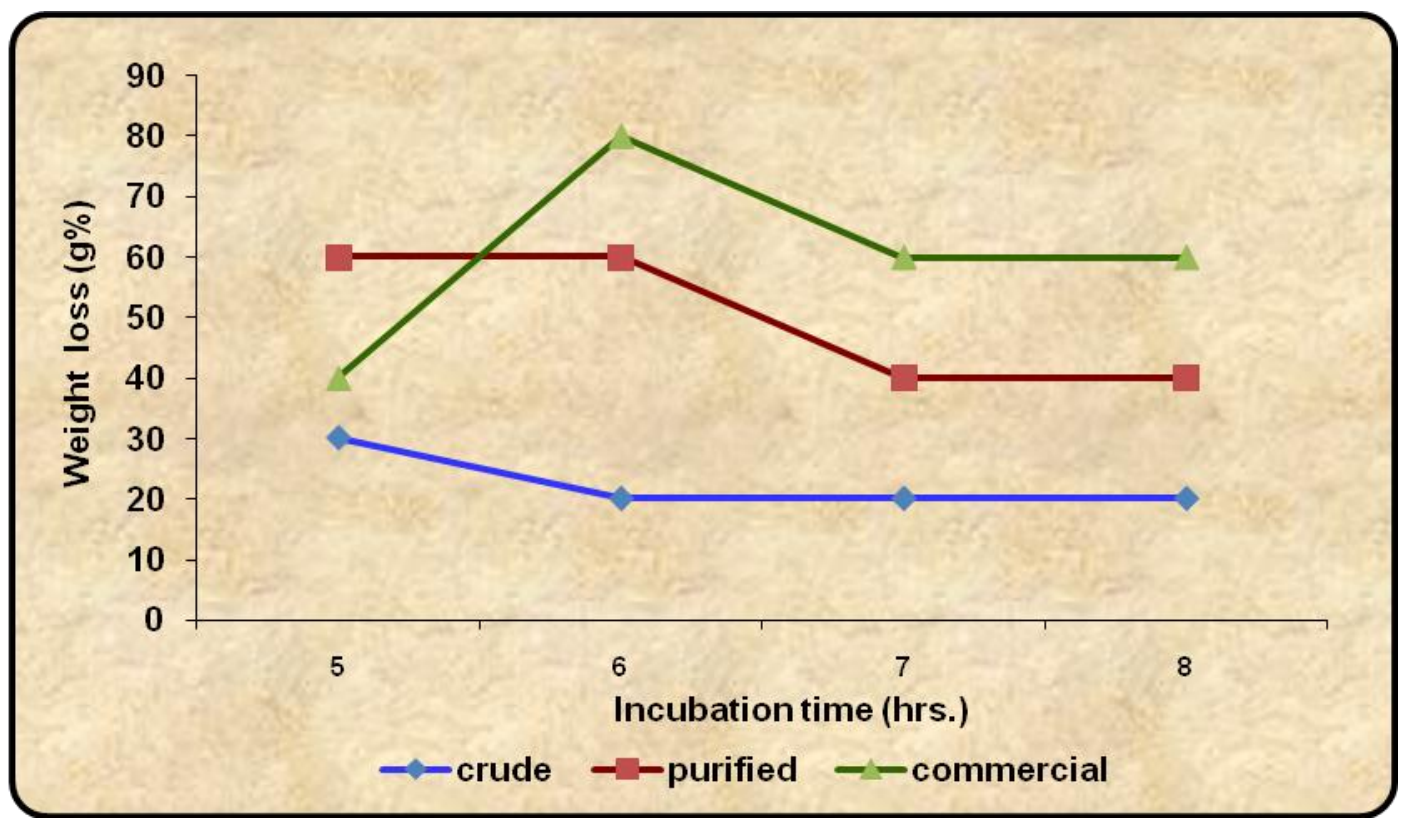

Fig.3 Optimization of $\mathrm{pH}$ for bioscouring by pectinase (wt. loss \%) at an optimum of $40 \%$ enzyme concentration for $4 \mathrm{hrs}$. of incubation time

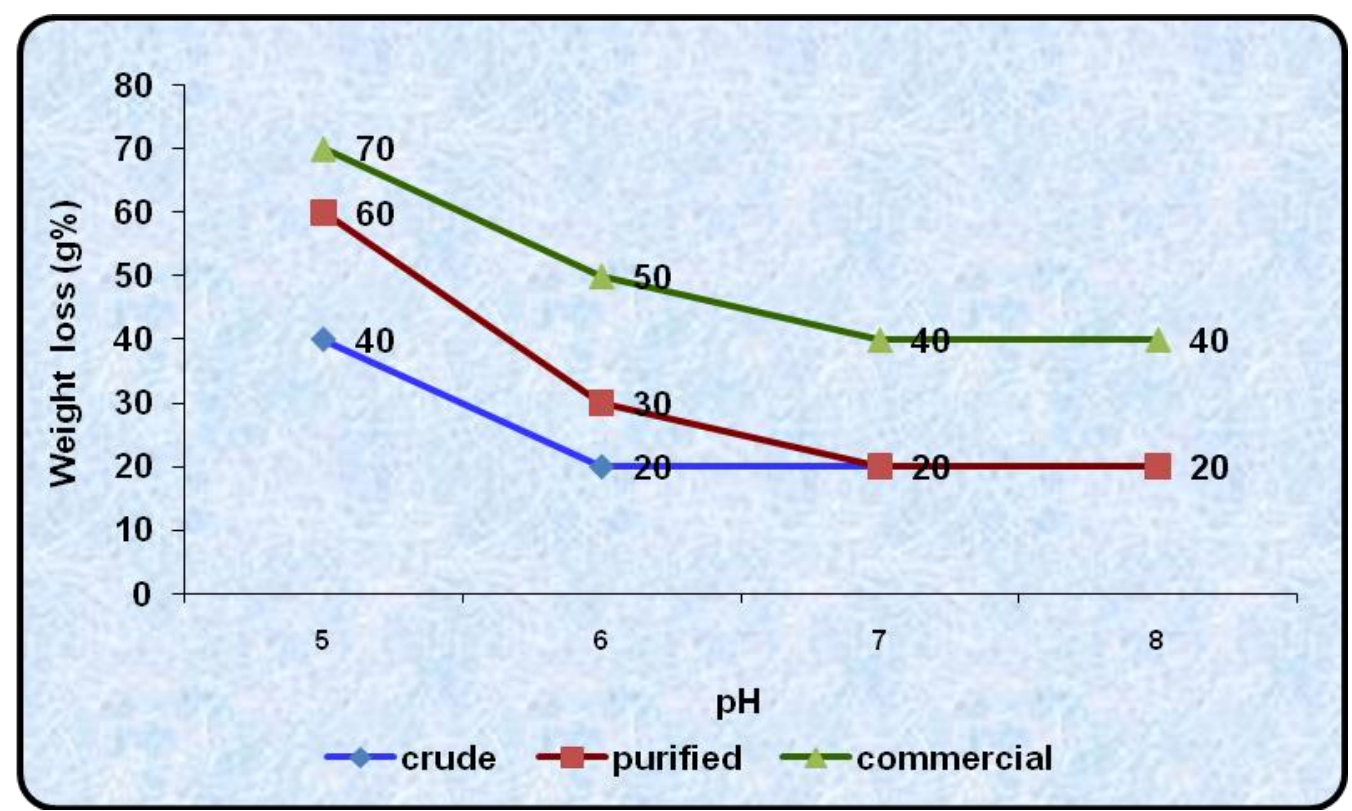


Fig.4 Optimization of temperature for bioscouring by pectinase (wt. loss \%) at an optimum of $40 \%$ enzyme concentration at $\mathrm{pH} 5.0$ for $4 \mathrm{hrs}$ of incubation time

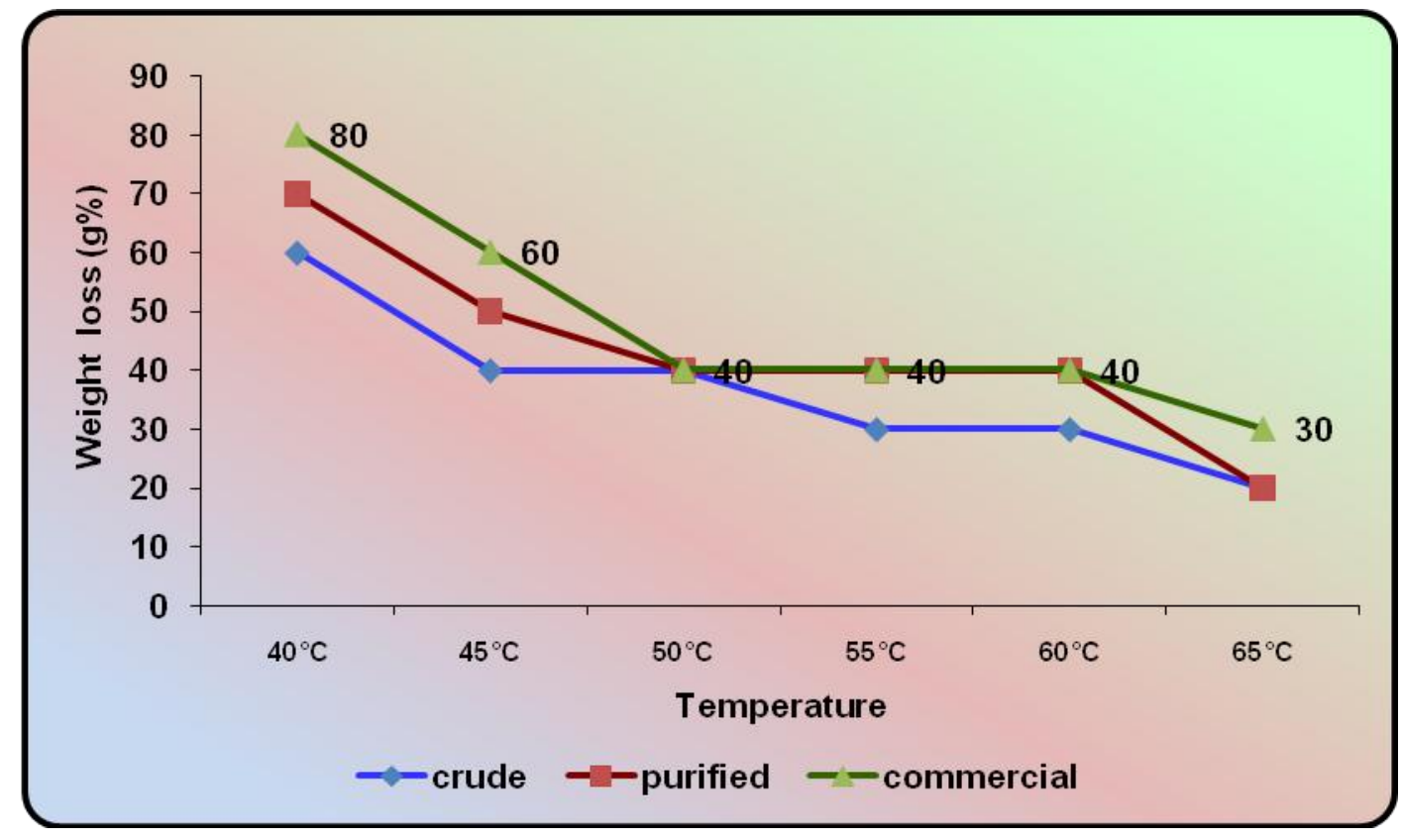

The present result coincides with the findings of Rajendran et al., (2011) who observed a maximum weight loss of the fabric when incubated at $40^{\circ} \mathrm{C}$ and the activity of the enzyme reduced considerably above $40^{\circ} \mathrm{C}$. Klug et al., (2006) reported that the bioscouring activity was found to be optimal even at a higher temperature of $60^{\circ} \mathrm{C}$.

In conclusion, it is clear from the Table 2, that the optimized conditions of pectinase treatment for bioscouring on pre-treated cotton fabrics were observed in 40 percent pectinase enzyme concentration, $4 \mathrm{~h}$ treatment time, $40^{\circ} \mathrm{C}$ and $\mathrm{pH}$ 5.0. Weight loss percent determines the extent of bioscouring.

Weight loss percent increases with an increase in enzyme concentration, but strength loss occurs at higher concentration. Therefore, 40 percent concentration was sufficient to produce effective surface smoothening and was determined to be the most efficient for better surface modification (above which, the effect was diminished). Each enzyme has an optimum temperature to exhibit maximum activity. All the pectinase treated samples showed the maximum enzyme activity at $40^{\circ} \mathrm{C}$, above which the activity decreased and still at higher temperatures the activity was stopped. Weight loss percent increased at $\mathrm{pH}$ 5.0, and there was gradual decrease upto $\mathrm{pH} 8.0$ due to loss of enzyme activity. Hence, $\mathrm{pH} 5.0$ was considered to be the optimum which proved the enzyme to be acidic. When treatment time was increased, weight loss percent also increased upto $4 \mathrm{hrs}$ but declined after 4 hrs.

\section{References}

Apoorvi, C., S. Vuppu. 2012. Microbially derived pectinases. J. Pharm. Biol. Sci., 2(2): 01-05.

Dalvi, P., P. Anthappan, N. Darade, N. Kanoongo, R. Adivarekar. 2007. Amylase and pectinase form single source for simultaneous desizing and scouring. Indian 
J. Fibre and Textile Res., 32: 459-465.

Harane, R.S., N.R. Mehra, B. Priti, Tayade and R.V. Adivarekar. 2014. A facile energy and water-conserving process for cotton dyeing. Int. J. Energy and Environ. Engi., 5: 96.

Hoondal, G.S., R.P. Tiwari, R. Tiwari, N. Dahiya and Q.K. Beg. 2000. Microbial alkaline pectinases and their applications: A review. Appl. Microbiol. Biotechnol., 59: 409-418.

Kapoor, M., Q.K. Beg, B. Bhushan, K. Singh, K.S. Dadich and G.S. Hoondal, 2001. Application of alkaline and thermostablepolygalacturonase from Bacillus sp. MG-cp-2 in degumming of ramie (Boehmerianivea) and sunn hemp (Crotolariajuncia) bastfibers. Process Biochem., 36: 803-817.

Kashyap, D.R., R.K. Vohra, S. Chopra and R. Tewari. 2001. Applications of pectinase in commercial sector, A Review. Biores. Technol., 77 : 215-227.

Klug, B. 2004. A new pectatelyase from Bacillus pumilus. Doctoral Thesis, Graz University of Technology, Graz, Austria.

Klug, B., W. Schnitzhofer, M. Vrsanska, J. Weber, P.B. Agrawal, V.A. Nierstrasz and G. M. Guebitz. 2006. Purification and characterization of a new Bioscouring pectatelyase Bacillus pumilus BK2. J. Biotechnol., 121: 390-401.

Prang Rocky, A.M.K.B. 2012. Comparison of effectiveness between conventional scouring $\&$ bio-scouring on cotton fabrics. Int. J. Sci. Engi. Res., 3(8): 1-5.

Prathyusha, K., V. Suneetha. 2011. Bacterial Pectinases and their Potent Biotechnological Application in Fruit Processing/Juice Production Industry: A Review. J, Phytol., 3(6): 16-19.

Prathyusha, K., V. Suneetha, M. Bishwambhar.
2011. Bacterial pectinases and their potent biotechnological application fruit processing / Juice production industry. J. Phytol., 3: 1619.

Rajendran, R., S. Karthik, R. Radhai and P. Rajapriya. 2011. Bioscouring of cotton fabrics using pectinase enzyme its optimization and comparison with conventional scouring process. Pak. J. Biol. Sci., 14: 519-525.

Rangarajan, V., M. Rajasekharan, R. Ravichandran, K. Sriganesh and R. Vaitheeswaran, 2010. Pectinase production from orange peel extract and dried orange peel solid substrates using Aspergillusniger. Int. J. Biotechnol. Biochem., 6(3): 445-453.

Samanta, A.K., D. Singhee and M. Sethia, 2003. Application of single and mixture of selected natural dyes on cotton fabrics: A scientific approach. Colourage, 50: 30-34.

Schimper, C.B., I. Constanta and B. Thomas, 2006. Technical aspects in enzymatic hydrolysis of cellulosics. LenzingerBerichte, 85: 107-112.

Siddiquee, A.B., M.M. Bashar, P. Sarker, T. T. Tohfa, M.A. Hossan, M.I. Azad and N. Akhtar. 2014. Comparative study of conventional and enzymatic pretreatment (scouring \& bleaching) of cotton knitted fabric. Int. J. Engi. Technol., 3(1): 37-43.

Sikder, M.M., A.I. Swazib and M.A. Islam. 2012. A comparative study between bio scouring and traditional scouring process in terms of time, cost \& energy. B.Sc Thesis, Daffodil International University, Dhaka, Bangladesh.

Tzanova, T., M. Calafellb, G.M. Guebitzc and A. Cavaco-Paulo. 2001. Bio-preparation of cotton fabrics. Enzyme and Microbial Technol., 29: 357-362.

\section{How to cite this article:}

Nisha, M.K., 2016. Process Optimization for Bioscouring of Cotton Fabrics with Pectinase Obtained from Paecilomyces variotii. Int.J.Curr.Microbiol.App.Sci. 5(6): 292-299. doi: http://dx.doi.org/10.20546/ijcmas.2016.506.033 